\title{
Notícia Sobre os Guarani que Reinvindicam a Terra de Araça'í
}

Kimiye Tommasino Em setembro de 2.000 a FUNAI constituiu um Grupo de Trabalho para fazer a identificação e delimitação de uma terra guarani nos municípios de Saudades e de Cunha Porã, em Santa Catarina. O GT Terra Indígena Guarani do Araça'í está sendo coordenado pela antropóloga Kimiye Tommasino, professora aposentada da Universidade Estadual de Londrina (PR).

Trata-se de um grupo guarani que foi expulso de sua terra pela Companhia Territorial Sul Brasil, que a loteou e vendeu a partir de 1920. Algumas famílias foram viver na Área Indígena Nonoai em Nonoai (RS). Outras ficaram pelos municípios da região de origem e sobrevivem trabalhando nas colônias como diaristas. Com a demarcação da terra kaingang de Nonoai, os Guarani passaram a ser pressionados: as terras onde formaram duas aldeias estão sendo reivindicadas pelos Kaingang, pois é a terra tradicional destes. Os Guarani passaram, então, a gestionar uma forma de retomar as terras de onde vieram. Lá se sentiriam em sua própria terra e não seriam hóspedes em terra alheia.

Em 1998 solicitaram à Administração Regional da Funai em Chapecó a constituição de um GT para retornar e retomar a Terra do Araça'í. Um funcionário foi designado para elaborar um levantamento preliminar, a fim de enviar a solicitação dos Guarani para que a presidência da Funai apoiasse a formação do GT. Os Guarani informaram da existência de dois cemitérios próximos às duas aldeias (Tekoa) que existiram na região entre os rios Araçá e Araçazinho. Apesar desses encaminhamentos, a Funai não providenciou o GT.

No dia 10 de julho de 2.000, portanto três anos depois, os Guarani decidiram ocupar uma área dentro da terra que consideram tradicional e lá 
permaneceram até o dia 19 de outubro, data em que foram despejados pelas polícias federal e militar, numa verdadeira operação de guerra. No dia 19 de outubro, às 6 horas da manhã, chegaram no local do acampamento guarani as polícias federal e militar com cerca de duzentos soldados. A polícia federal ordenou ao cacique que avisasse as famílias que tinham sete minutos para deixarem os barracos e entrarem nos ônibus que estavam esperando. Caso não obedecessem, entrariam em ação os soldados da polícia militar, com cassetetes e bombas de gás, a postos a poucos metros dali.

Segundo o depoimento do cacique, eles nem esperaram sete minutos e já entraram no acampamento com moto-serras, destruindo os barracos, e com as mãos arrancaram as lonas plásticas dos barracos. Chegaram a colocar fogo num deles. Os repórteres da RBS estavam no local e algumas cenas do despejo foram apresentadas no noticiário do meio-dia, mas foram proibidos de filmar o trabalho das moto-serras e a queima do barraco. O J uiz Federal de Chapecó concedeu liminar de reintegração de posse ao madeireiro Zimmer, proprietário da área ocupada pelos Guarani. Apesar de os Guarani terem solicitado à polícia militar que queriam ficar na rodovia próximo a Araça'í, eles foram levados de volta para a Área Indígena Nonoai e lá estão acampados numa pequena área de mata próxima à sede do Posto.

Em setembro, quando estava prestes a vencer o prazo concedido pelo J uiz em Chapecó, a Funai constituiu o Grupo Técnico para a identificação e delimitação da Terra Guarani. Os estudos estão sendo realizados sob clima de tensão. Os prefeitos de Saudades e Cunha Porã, seus advogados, representantes dos colonos e sindicatos se somaram contra a reivindicação dos Guarani e constituíram o Movimento em Defesa da Propriedade e da Dignidade, que é encabeçado pelos prefeitos. Mas os estudos estão em andamento e o relatório final deverá estar concluído até março de 2.001. 